\title{
NA COLÔNIA: IMAGENS, SABERES E SABORES PARTILHADOS
}

\author{
Patrícia dos Santos Pinheiro ${ }^{1}$ \\ Carmen Janaina Machado ${ }^{2}$ \\ Claudia Turra Magni ${ }^{3}$ \\ Renata Menasche ${ }^{4}$
}

A Serra dos Tapes, região ao sul do Rio Grande do Sul que compreende, entre outros, os municípios de Pelotas, São Lourenço do Sul e Canguçu, é habitada por grupos camponeses de diferentes origens e identidades étnicas, cujos modos de vida são aqui abordados tendo a comida e a imagem como objetos, símbolos e instrumentos de partilha, mediação e diálogo da agenda de pesquisa "Saberes e Sabores da Colônia". Conduzida pelo Grupo de Estudos e Pesquisas em Alimentação e Cultura (GEPAC), em associação com o Laboratório de Estudos Agrários e Ambientais (LEAA) e com o Laboratório de Ensino, Pesquisa e Produção em Antropologia da Imagem e do Som (LEPPAIS), vinculados ao Instituto de Ciências Humanas da Universidade Federal de Pelotas (UFPel), nessa agenda de pesquisa a observação de práticas alimentares foi tomada como abordagem para o estudo do rural, a partir de receitas herdadas, pratos tradicionais, produtos e ingredientes locais, espécies e variedades nativas, práticas da alimentação cotidianas ou rituais, utensílios e objetos $^{5}$.

Essas práticas e saberes estão associadas à cultura material, à produção e ao consumo de alimentos, aos mecanismos de sociabilidade em que ocorre sua circulação e aos espaços em que se realizam atos associados ao comer, conformando sistemas culinários cuja diversidade é expressão de modos de vida e visões de mundo de grupos sociais específicos, marcando pertencimentos e distinções identitárias. O desafio de buscar de

\footnotetext{
${ }^{1}$ Universidade Federal de Pelotas, Brasil.

${ }^{2}$ Universidade Federal do Rio Grande do Sul, Brasil.

${ }^{3}$ Universidade Federal de Pelotas, Brasil.

${ }^{4}$ Universidade Federal de Pelotas e Universidade Federal do Rio Grande do Sul, Brasil.

${ }^{5}$ Com financiamento do $\mathrm{CNPq}$, através do projeto "Cultura, patrimônio e segurança alimentar entre famílias rurais: etnografias de casos significativos" (CNPq 559565/2010-0) e da Fapergs, com o projeto "Saberes e Sabores da Colônia: modos de vida e patrimônio alimentar entre pomeranos no Brasil meridional" (Fapergs 1018354/2010-6).
}

Iluminuras, Porto Alegre, v. 16, n. 40, p.11-44, ago/dez, 2015. 
algum modo contemplar esta complexidade, herdeira de tradições e sujeita a dinâmicas e transformações, levou-nos a recorrer às imagens como vetor e catalisador da pesquisa, desde a elaboração do projeto, passando pelo trabalho de campo, a análise do material empírico, a elaboração dos resultados e sua recepção, via restituição e circulação dos produtos imagéticos - etapa de um diálogo potencialmente infinito.

O propósito deste artigo é relatar e refletir sobre esse percurso coletivo suscitado pelas comidas e pelas imagens, enquanto vetores, mediadores e catalisadores da pesquisa e de seus desdobramentos. Procederemos, em um primeiro momento, à contextualização do universo de pesquisa para, na sequência, passar ao relato do percurso de elaboração dos produtos imagéticos (um box multimídia - contendo um CD interativo, dez vídeos documentários e um livro de receitas -, além de uma exposição de dez painéis com imagens e textos), desenvolvidos no âmbito do Leppais ${ }^{6}$. Na sequência, serão tomados como casos para análise as pesquisas etnográficas realizadas na Colônia Maciel, em Pelotas, e em três comunidades quilombolas de São Lourenço do Sul (Vila do Torrão, Picada e Rincão das Almas), assim como o material imagético resultante dessas inserções de pesquisa ${ }^{7}$. O artigo prossegue com uma análise sobre o encontro entre protagonistas, pesquisadores e comunidades rurais, com novas reflexões suscitadas por esses eventos de devolução da pesquisa e partilha de saberes.

\footnotetext{
${ }^{6} \mathrm{O}$ desenvolvimento dos produtos imagéticos aqui referidos deu-se em parceria com o artista plástico Mauro Bruschi'.

${ }^{7}$ Referente à Colônia Maciel foram produzidos dois vídeos: "Família Camelato, do vinho e do suco" - que tem direção de Carmen Janaina Machado, imagens de Carmen Janaina Machado e Caio Mazzilli e operação de edição de Caio Mazzilli, Hamilton Bittencourt e Carmen Janaina Machado; e "Festa na Colônia, Festa de Sant'Ana”, cuja direção é também de Carmen Janaina Machado, imagens de Carmen Janaina Machado, Evander Krone e André Bonifácio e operação de edição de Caio Mazzilli, Hamilton Bittencourt e Carmen Janaina Machado. Já referentes às comunidades quilombolas, os vídeos "Carneação de Porco", "Schimia de melancia de porco" e "Memórias negras sobre a alimentação" tiveram direção de Patrícia dos Santos Pinheiro e imagens e edição de Patrícia dos Santos Pinheiro e Carolina Vergara Rodrigues, enquanto que o vídeo "Terno de Reis" teve direção, imagens e edição de Patrícia dos Santos Pinheiro e Carolina Vergara Rodrigues. Todos esses vídeos estão disponíveis, juntamente com os demais produzidos no âmbito da agenda de pesquisa "Saberes e Sabores da Colônia", em: http://www.ufrgs.br/pgdr/gepac/videos.html.
} 


\section{A diversidade étnica da ocupação da Serra dos Tapes}

As coxilhas e serranias das Serra dos Tapes, habitadas mais intensamente por populações autóctones da tribo Tape, tronco Tupi Guarani, e pelos Minuano até pelo menos o século XVII (Costa, 2007; Maestri, 2002), foram, no período colonial, consideradas fundo territorial de pecuaristas luso-brasileiros, tanto aqueles que possuíam estâncias nas terras baixas da Planície Costeira, próximas da Laguna dos Patos, quanto os charqueadores de Pelotas. Desde o início da ocupação europeia, entretanto, esta região acolheu, juntamente com os imigrantes de origem europeia, inúmeros outros grupos (para além dos indígenas também presentes), como populações negras libertas, quilombolas e lavradores nacionais, que ocuparam a região, frequentemente de maneira itinerante.

A intensificação da colonização sul-rio-grandense no século XIX deu-se, segundo Zarth (2002), em um contexto em que a elite luso-brasileira local viu no processo de colonização uma oportunidade de enriquecimento pela especulação fundiária, vendendo terras não usadas na pecuária para agências de colonização. Como aponta o autor, ao mesmo tempo em que essas políticas disponibilizaram terras como incentivo à imigração mais de 20 núcleos coloniais, com imigrantes alemães, franceses, italianos e pomeranos, foram implementados pela iniciativa privada na Serra dos Tapes -, elas estimularam o Estado a marginalizar negros, lavradores nacionais e populações indígenas, que moravam nos espaços "vazios", ocupados por acesso livre costumeiro à terra.

Dentre os núcleos coloniais europeus não portugueses dessa Serra, um empreendimento pioneiro foi à colônia de São Lourenço, formada em 1858 com imigrantes de origem pomerana na Freguesia de Nossa Senhora do Boqueirão - área que pertencia à antiga delimitação de Pelotas e posteriormente veio a compor o município de São Lourenço do $\mathrm{Sul}^{8}$. Ressalta-se que, segundo Bosenbecker (2011), as origens dos moradores desse povoado eram diversas na época da implantação da colônia ${ }^{9}$. Além disso, nessa mesma área

\footnotetext{
${ }^{8}$ A extinta Pomerânia atualmente englobaria parte da Alemanha e da Polônia. Também há núcleos de colonização no Espírito Santo e em Santa Catarina, que se desdobraram para outros locais.

9 Bosenbecker (2011), com dados do livro de registros católicos, datados entre 1848 e 1870 , indicou que a Freguesia tinha, além de moradores sul rio-grandenses do local e das cidades próximas, também portugueses, brasileiros, de diversas regiões, espanhóis, argentinos, uruguaios, um paraguaio, franceses e italianos (comerciantes). Pelos registros de nascimento de 1947-1958, ela identifica ainda indígenas, alemães, um guineense, um irlandês e cativos.
} 
também ocorreu a formação, ainda no século XIX, de diversas comunidades negras rurais identificadas como quilombos.

Outro núcleo colonial que compõe um contexto de diversidade étnica que caracteriza a região colonial de Pelotas é a colônia Maciel, criada pelo governo provincial entre 1881 e 1882 e ocupada efetivamente entre 1883 e 1884. Segundo a historiografia local, a colônia Maciel apresenta-se como a mais representativa da imigração italiana na região de Pelotas. Além dos imigrantes italianos, sua formação social contou com a presença de alemães, pomeranos, franceses, africanos e seus descendentes (Machado, 2011).

A partir desses processos de ocupação da região, atualmente os núcleos coloniais da Serra dos Tapes estão inseridos em estruturas de alteridade que não podem ser desprezadas em sua importância na conformação das relações sociais locais. Pensando nos processos identitários que perpassam os grupos étnicos, habitam essa região diferentes grupos, que estabelecem variáveis de interdependência, seja a partir do conflito e da estigmatização ou através de códigos e afetos partilhados.

No limiar das demarcações identitárias, a delimitação de identidades é acionada por categorias como colonos (com variações de acordo com a origem do grupo), morenos (negros) e brasileiros, pejorativamente também chamados de tucas ou birivas ${ }^{10}$. Inseridas nas tortuosas e móveis fronteiras étnicas e raciais, se, por um lado, destacam-se algumas características e condições de vida dinâmicas que se combinam e poderiam indicar uma segmentação estrita entre esses grupos - por exemplo, há marcadores como a língua, tradições culturais etc. -, por outro uma série de delimitações de fronteiras são constantemente tensionadas e reformuladas: os bailes que outrora eram oficialmente separados já não o são, enquanto são mais frequentes casamentos, compadrios e relações de amizade entre membros de diferentes grupos étnicos (ou com pessoas oriundas de núcleos urbanos), bem como são compartilhados símbolos religiosos, entre outros elementos e fatores (Pinheiro, 2015; Schneider, 2015).

${ }^{10}$ Com algumas oscilações de significados, os tucas são indicados como aqueles que não são nem de ascendência teuto, nem negra, podendo designar a mistura entre indígenas, descendentes de portugueses ou outros e, em certos casos, um não enquadramento em termos de pertença étnica. Em especial essa posição ocupada pelos brasileiros, termo que frequentemente é conferido externamente pela negação (não é colono nem moreno), pode parecer uma borda: ora dialogam mais com afrodescendentes, ora com colonos, ou ainda se destacam como a elite latifundiária. 
Com isso, o que se percebe é o intenso contato, trocas e comunicação que atravessam os distintos grupos, interação que, no entanto, não finda com as fronteiras, mas de maneira dinâmica, constrói ou consolida elementos e categorias de exclusão e de aproximação entre eles, contando também com transformações individuais e releituras de critérios de pertencimento, como no caso dos casamentos interétnicos. É preciso ressaltar que, para além das identificações e delimitações, esses grupos étnicos não conformam grupos coesos, homogêneos ou fechados. Há uma série de nuances, parcerias estratégicas e aproximações por afinidade e, ao atentar para as intersecções entre diferentes formas de pertencimento, percebe-se que não há enquadramento único e homogêneo para cada grupo.

Diante da variedade e riqueza existentes neste universo rural, os trabalhos que compuseram esta agenda de pesquisa, indicados na Figura a seguir (Figura 1), procederam a distintas aproximações com realidades singulares, interseccionadas pelos olhares particulares de pesquisadores com formações e perspectivas diversas no âmbito das ciências humanas.

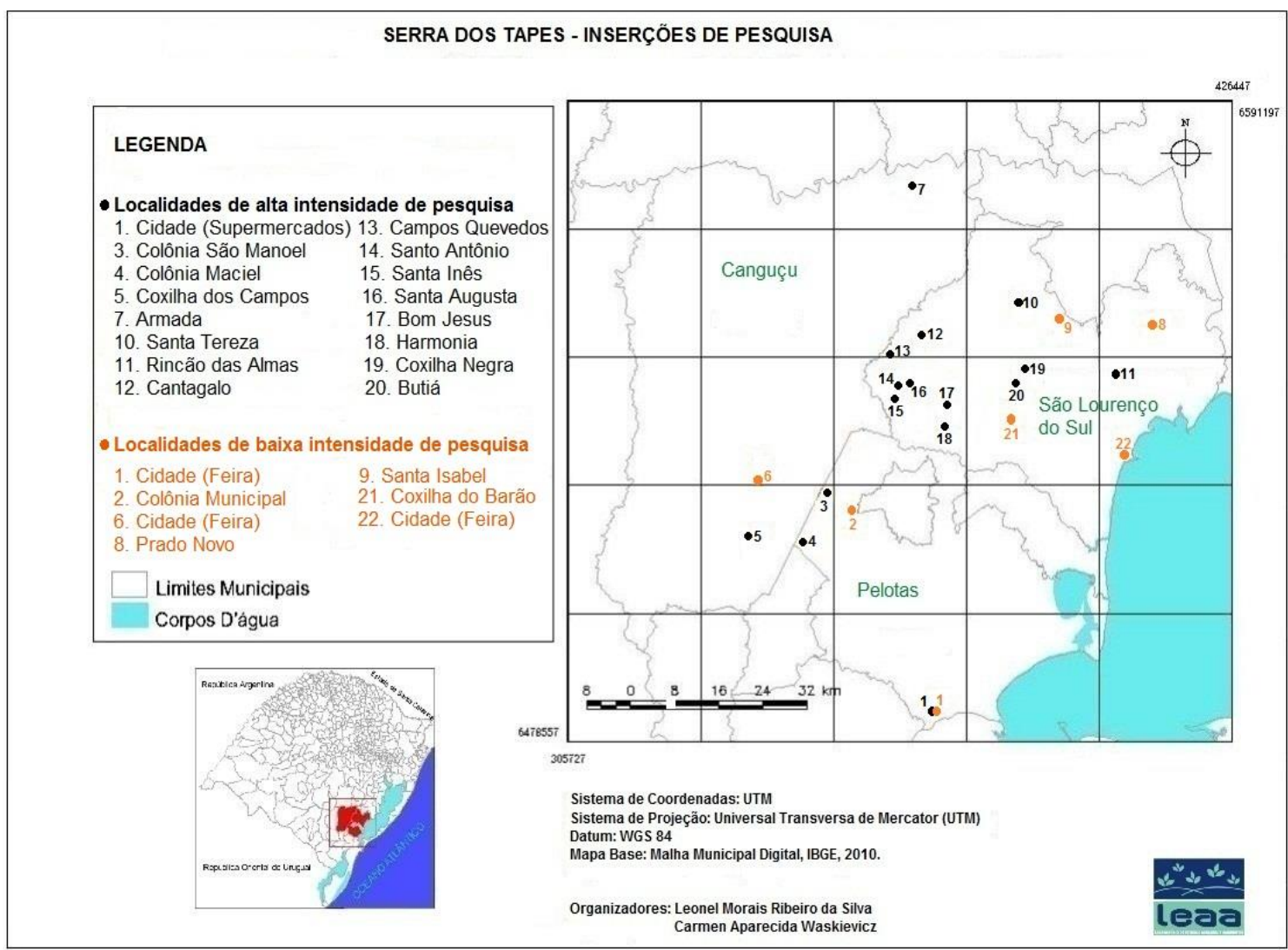

Figura 1: mapa com as localidades de inserção de pesquisa.

Fonte: Laboratório de Estudos Agrários e Ambientais (2013). 
Em termos de produção, atualmente as famílias rurais da colônia Maciel comercializam, em sua maioria, pêssego, fumo e tomate. Em São Lourenço do Sul, o fumo é o principal produto comercializado, seguido por itens como feijão, milho, batata e batatadoce. Nesses e em outros núcleos coloniais da Serra dos Tapes também é realizada a comercialização de produtos como queijo, vinho, suco de uva, mel e ovos. Além disso, é produzida uma série de itens destinados ao autoconsumo, tais como batata, batata-doce, abóbora, hortaliças, feijão, milho, tomate, pimentão, morango, laranja, pêssego, leite, mel e ovos. Essa diversidade de alimentos, proveniente da horta, pomar, lavoura e criações, relacionam-se a uma heterogeneidade de saberes e práticas que conformam a região colonial da Serra dos Tapes.

Essa configuração proporcionou à agenda de pesquisa Saberes e Sabores da Colônia a possibilidade de abordar diferentes práticas e saberes alimentares de sujeitos que, embora partilhem vivências no mundo rural e pertençam aos mesmos espaços, constituem núcleos coloniais que fazem parte de imbricada rede de relações, não restritas por fronteiras entre grupos sociais, em que proximidade e distância convivem e signos de diferença podem modificar-se ao longo do tempo.

\section{A produção imagética na pesquisa: percurso e perspectivas}

As interações entre o mundo rural, a comida e a imagem conformam os pilares fundamentais a partir dos quais a agenda de pesquisas Saberes e Sabores da Colônia é pensada neste artigo. As relações, correspondências e entrelaçamentos entre os pilares deste tripé convidam a pensar na comida da colônia e nas imagens produzidas neste contexto de pesquisa enquanto agentes de disseminação, ou vetores, de um saber fazer a ser salvaguardado. Ademais, diante dos processos de restituição e recepção dos dados etnográficos, as imagens aparecem como catalisadores, com potencial de acelerar e dinamizar as reações dos sujeitos singulares e coletivos que constituem a rede de interlocutores envolvidos com os destinos, usos e o agenciamento do patrimônio alimentar em questão. 
A produção de imagens e de comidas, diversamente da visão e da alimentação, que constituem condições biológicas vitais generalizadas, é uma especificidade humana e, de forma reflexiva, ocupa importância central na humanização da espécie. Atravessadas por simbolismos, comidas e imagens são universalmente verificadas, embora culturalmente diferenciadas. Polissêmicas por excelência, mesmo sem recorrer a informações linguísticas, elas portam signos que comunicam normas, sentidos, tabus (Barthes, 1961; Lévi-Strauss, 1976, 1979) e ainda são capazes de revelar identidades e valores socioculturais (Maciel; Menasche, 2003; Maciel, 2005; Rial, 2005).

Diante disso, o grande desafio colocado aos membros da equipe, a maioria com/em formação nas Ciências Humanas, foi o de apropriarem-se de linguagens visuais capazes de evocar um objeto tão complexo e polissêmico quanto as comidas dessas colônias, com seus valores intrínsecos relacionados a fronteiras, interseções e transversalidades étnicas. Para além da mera documentação visual de paisagens e sujeitos em seus ambientes e cenários característicos, com respectivos elementos, instrumentos, processos de fabricação e consumo alimentares, a dificuldade maior era abarcar aspectos impalpáveis e não ditos relacionados àquele tipo de comida, enquanto fenômeno total e pleno de significados, vital e estruturante das comunidades estudadas. Assim, na medida em que a comida está relacionada a pregnâncias e ressonâncias ativadas por experiências subjetivas, memórias coletivas, valores, normas, saberes e práticas sociais, questionávamos como descrever e transmitir, de forma densa, sabores, gostos, aromas, sensações, desejos, lembranças, afetos, gentilezas, pertencimentos, receios, discórdias, rupturas e outros aspectos e fenômenos intangíveis evocados pela comida.

A provocação, acolhida pelo Leppais, levou ao desenvolvimento de oficinas de imagem com a equipe de pesquisa, que se engajou em um processo de iniciação, reflexão, construção e partilha acerca dos fundamentos teórico-metodológico e da prática com fotografia, vídeo e multimídia. A concepção coletiva e escolha dos múltiplos temas que ganharam relevância ao longo do processo de pesquisa, passando pelas estratégias e técnicas de trabalho de campo com imagens, até a edição e organização do vasto corpus imagético gerado pelo trabalho, desdobrados na restituição dos produtos imagéticos, por sua vez também documentados em audiovisual, foram experiência nova para a maioria dos 
participantes, ao menos com a abrangência e diversidade a que se propunha a agenda de pesquisa.

À medida em que a pesquisa se desenvolvia, além de propiciarem a capacitação, experimentação e a reflexão de forma e fundo sobre as imagens realizadas, assim como sua articulação com os elementos verbais (orais e textuais) da pesquisa, estas oficinas conformaram-se em espaços de relatos das distintas experiências de campo entre a equipe, fomentando um investimento de aprendizado e discussão para cada uma das diferentes comunidades rurais da região da Serra dos Tapes que participaram do estudo ${ }^{11}$.

Estas oficinas periódicas, descritas detalhadamente por Turra-Magni et al. (2015) como um modo de "oxigenação" dos trabalhos etnográficos em andamento, alternaram momentos de "inspiração" - através de visualizações de filmes e ensaios fotográficos, audição de trabalhos sonoros, explanação e experimentação de recursos técnicos e leituras de obras de referência - com momentos de "expiração" - em que os participantes restituíam para a equipe os registros imagéticos, acompanhados de suas pretensões, impressões e apreensões quanto a seus usos, significados e desdobramentos ${ }^{12}$. Tais contribuições e problematizações coletivas foram especialmente importantes para o trabalho de edição dos dez vídeos realizados, cujo principal intuito era a restituição do trabalho para as famílias acolhidas pelos pesquisadores. A metáfora da oxigenação proporcionada pelas oficinas de imagem no desenvolvimento do processo coletivo de pesquisa encontra ressonância na argumentação de Marcus Banks (2014), quando adere a uma Slow Science, em associação à Slow Food e ouros movimentos contemporâneos de resistência à aceleração doentia da produtividade. Para ele, as imagens ajudam-nos a "digerir" e explorar mais amplamente a profundidade e as múltiplas facetas de nossas experiências etnográficas.

\footnotetext{
11 A equipe pode compartilhar reflexões e metodologias, mas ressalta-se que em geral os pesquisadores atuaram em campo separadamente, salvo iniciativas de interação em que os pesquisadores participavam de modo auxiliar de saídas de campo referentes a iniciativas de outros pesquisadores da equipe, em locais da Serra dos Tapes distintos de seus próprios campos de pesquisa.

${ }^{12}$ Tratando-se de um processo contínuo de aprendizagem, nesses momentos de "expiração" era possível refletir sobre o processo de elaboração fílmica à medida em que as imagens eram produzidas e, a partir disso, avaliar possíveis reordenamentos e complementos. Por exemplo, houve casos em foi necessário refazer algumas filmagens: é o que se deu em referência ao registro da feitura de um alimento cujas imagens não haviam sido captadas depois de pronto - falha decorrente da pouca experiência na produção fílmica. Foram, ainda, inúmeras as situações adversas, como na filmagem da carneação de porco, em que a chuva trouxe uma série de desafios tanto para a realização da prática em si como para sua filmagem, que precisou ser interrompida por dificuldades técnicas (tendo o registro imagético seguimento apenas com fotos), o que gerou adaptações na edição das imagens.
} 
Uma vez que a comida e os modos de vida a ela relacionados foram concebidos neste projeto enquanto fato social total, as imagens não podiam ser tratadas como fragmentos, como singularidades ou exceções, mas sim como expressões de contextos, como conexões de estruturas e de processos de mudanças, com as rupturas e choques daí decorrentes. Assim, no intuito de reunir o material etnográfico dos trabalhos com distintos grupos comunitários da Serra dos Tapes, resgatando os aspectos materiais e intangíveis que fazem das comidas vetores plenos de significação de acordo com seus respectivos sistemas culinários, desenvolveu-se um produto multimídia contendo fotos, textos e clipes dos dez vídeos realizados.

Diversamente dos vídeo-documentários, destinados mais especificamente à restituição das pesquisas às famílias e interlocutores privilegiados, este cd-rom interativo foi pensado como forma de difusão da pesquisa para um público mais abrangente. Para tanto, as sessões finais das oficinas destinaram-se a reunir o vasto e profuso material imagético produzido, retomando de modo mais integrado os propósitos e perspectivas do projeto, operando sistematizações e seleções, reavaliando títulos, legendagens, discutindo eixos e categorias agregadoras dos temas e conjuntos analíticos abordados nessas imagens ${ }^{13}$. Um livreto com as principais receitas étnicas recolhidas entre interlocutores (com a nomeação de quem forneceu cada receita) completa o kit de produtos, disponível em duas versões: uma com e outra sem o cd-rom contendo os dez documentários (os quais estão também disponibilizados na web, como já mencionado).

Finalmente, dentre o conjunto de produtos imagéticos encontra-se ainda uma exposição de dez painéis em banners, que abordam os principais temas da pesquisa, com pequenos textos, fotografias e, em destaque, uma imagem fotográfica com efeito pictórico. Este conjunto, destinado à apresentação em locais públicos, foi previsto e está sendo exposto em ocasiões festivas nas colônias, assim como em núcleos urbanos das cidades.

Por outro lado, um livro (Menasche, 2015) compila reflexões referentes às diversas experiências de pesquisa. Se tanto textos quanto imagens produzem ideias, cada qual com suas características e limites, essa complementaridade na reflexão etnográfica foi pensada também no sentido de englobar linguagens diferentes e produzir material que possibilitasse àquele que o lê, vê e/ou ouve, promover sua própria exegese.

\footnotetext{
${ }^{13}$ Para maior detalhamento do conteúdo do cd-rom, ver Turra-Magni et al., 2015.
} 
Assim, se num primeiro momento as imagens produzidas neste contexto aparecem como vetores da pesquisa sobre as comidas (elas próprias, também agentes de disseminação de saberes), percebe-se que a importância dos processos e produtos imagéticos não se limitou ao enriquecimento e detalhamento de dados empíricos a serem salvaguardados por outrem. Seja na interação estabelecida entre os membros da equipe, seja naquelas ocorridas entre eles e os grupos estudados, as imagens constituíram-se como formas comunicacionais, capazes de gerar e acelerar reações, dinamizar, fortalecer e potencializar vivências e compartilhamentos. Diante desse percurso metodológico, é possível afirmar que as imagens foram catalisadores, dispositivos transversais, integradores e relacionais dos diversos subgrupos, agentes e instituições que constituem e extrapolam a pesquisa, potencializando outras formas de pensar em termos patrimoniais, como as relatadas a seguir, a partir de algumas experiências de produção fílmica tomadas como estudos de casos exemplares do processo mais abrangente.

\section{A experiência compartilhada dos vídeos}

A partir da dinâmica da triangulação mundo rural/comidas/imagens, tal como antes referida, tomou-se como premissa, corroborada pela experiência prática, o entendimento de que os filmes etnográficos não apresentam, objetiva e realisticamente, o Outro, mas representam-no, de modo sempre refratário, a partir das especificidades do encontro com a alteridade, revelando tanto ou mais a perspectiva de quem filma do que o Outro filmado. Percebe-se, portanto, como a relação entre Cinema e Antropologia se insere na reflexão epistemológica sobre o desenvolvimento da pesquisa antropológica e as relações de alteridade subjacentes a esse contato.

Esse debate se modificou bastante ao longo do tempo - de uma ênfase inicial nas diferenças, catalogações e classificações das diversas culturas, para outra, com a qual compartilhamos, focada na troca entre olhares e nos significados construídos a partir das interações $^{14}$-, mas de modo permanente há uma problematização da discussão sobre a alteridade e sobre os modos de ver na construção do percurso etnográfico que acompanha as imagens.

\footnotetext{
${ }^{14}$ Para uma cronologia e síntese da aproximação entre Cinema e Antropologia, ver Heider (1995), Piault (2000), Cunha e Barbosa (2006), entre outros.
} 
Sob essa perspectiva, Salles (2005) aponta para um esforço - acentuado nos últimos anos - do cinema documental no sentido de expressar em narrativas a natureza da relação entre sujeitos:

\begin{abstract}
São filmes sobre encontros. Nem todos são bons, mas os melhores tentam transformar a fórmula eu falo sobre ele para nós em eu e ele falamos de nós para vocês. Desse encontro nasce talvez uma relação virtuosa entre episteme e ética. Filmes assim não pretendem falar do outro, mas do encontro com o outro. São filmes abertos, cautelosos no que diz respeito a conclusões categóricas sobre essências alheias. Não abrem mão de conhecer, apenas deixam de lado a ambição de conhecer tudo. (Salles, 2005; p. 70, grifo do autor).
\end{abstract}

O que a câmera potencializa ou altera da relação entre pesquisadores e interlocutores segue pertinente para os debates sobre o trabalho antropológico. Para além de uma comprovação através de imagens, o registro fílmico pode ser um instrumento de comunicação entre sujeitos, em determinada realidade etnográfica, sem esquecer que a visão do pesquisador também tem intencionalidade e é construída social e culturalmente. Essas reflexões foram impulsionadas pelas obras de pesquisadores como o antropólogo/cineasta Jean Rouch, que dá ênfase à relação construída com e a partir do filme, a verdade fílmica (que se propõe a desestabilizar uma ideia de verdade, de alteridade e do modo de fazer etnografia), que por sua vez desperta relações para além dele, em sua recepção junto aos espectadores (Barbosa; Cunha, 2006) ${ }^{15}$.

Contribuindo com o debate, Vale (2014) discorre sobre a complexidade do trabalho de campo e do processo de elaboração fílmica e, a partir daí, sobre relações e aprendizados que se estabelecem, em um compartilhamento de experiências concretas entre sujeitos:

O fato de que o uso de uma câmera no trabalho de campo deve ser pensado como catalizador de relações e não como um mero instrumento de coleta de material empírico, implica também que sua introdução no contexto de uma pesquisa é dependente de uma série de fatores e não pode se dar de forma irrefletida. $\mathrm{O}$ resultado desse trabalho não apenas intensifica a dimensão ética das experiências de pesquisa - na medida também em que o registro visual possui um alcance mais amplo do que o registro escrito -, mas atua

15 Os filmes do chamado cinema-verdade, inaugurados por Rouch, evocam ambiguidades e promovem questionamentos sobre processos políticos, éticos e epistemológicos da Antropologia. Na produção do evento fílmico-etnográfico rouchiano, subjaz um estilo de construção compartilhada de conhecimento inspirado no movimento surrealista que faz do filme uma forma de expressão sui generis, na qual a ficcionalização, a imaginação e o imaginário são recursos potentes para a entrada no universo do Outro, assim como para a diluição das fronteiras ideológicas (e igualmente ficcionais) na relação com a alteridade (Gonçalves, 2007).

Iluminuras, Porto Alegre, v. 16, n. 40, p.11-44, ago/dez, 2015. 
como mediação privilegiada no conhecimento da experiência subjetiva de nossos/nossas interlocutores/as. (Vale, 2014; p. 169-170, grifo do autor).

Os compartilhamentos na produção fílmica podem se dar sob diferentes perspectivas. Em uma situação ideal, há participação constante dos interlocutores, incluindo o manejo dos equipamentos e a apropriação contínua da produção. Mas essa forma de participação nem sempre consiste em possibilidade viável ou desejada pelos interlocutores, como descrito na pesquisa elaborada por Vale (2014) junto ao espaço cultural em torno do Cine Jangada ${ }^{16}$. No caso aqui descrito, a participação na pesquisa não necessariamente se deu com o manejo partilhado das ferramentas de filmagem ou de fotografia, mas com o compartilhamento de uma relação entre sujeitos, em que do trabalho de campo emergem reflexões, diálogos, opiniões, conduções, escolhas e construções que levaram aos produtos imagéticos. Com isso, de diferentes maneiras e intensidades, os pesquisadores participaram de momentos importantes da vida de comunidades rurais da Serra dos Tapes.

As trocas entre interlocutores e pesquisadores com imagens e versões prévias apresentadas ao longo do processo teve diferentes intensidades entre as frentes de pesquisa congregadas na agenda Saberes e Sabores da Colônia. Um elemento subjacente a essa conformação é a própria relação entre interlocutores e pesquisadores que se estabelece ao longo da pesquisa antropológica. Cabe mencionar que essa relação nem sempre é de proximidade, por ser tributária e potencial geradora de determinadas relações de poder, que também se baseiam em hierarquias sociais (reforçadas pelas posições acadêmicas), potência essa que pode ser desconstruída ou dissolvida em alguma medida, a partir de constante vigilância crítica, mas que sempre se constitui em desafio, sendo que em cada contexto vivenciado em pesquisa etnográfica, com imersões em práticas, subjetividades e dinâmicas, são estabelecidas relações singulares.

Para Fabian (2006), a pesquisa etnográfica deve se basear na intersubjetividade que se cria a partir da interação comunicativa entre sujeitos, para além da "coleta" de dados. Para tornar possível essa interação, o autor argumenta em favor da reflexão sobre o compartilhamento do tempo, problematização para a qual designa o termo coetaneidade

16 O Cine Jangada foi um cinema situado no centro de Fortaleza que realizava exibição de filmes pornográficos, com uma multitude de sociabilidades que se desenvolviam junto com a exibição dos filmes, descritas por Vale (2014). 
(coevalness), questionando o colonialismo da Antropologia. Para o autor, justamente a ruptura com a coetaneidade permitiria hierarquizar povos e culturas, que por viverem temporalidades distintas, estariam posicionados inferiormente. Propondo outra perspectiva, Fabian menciona a coetaneidade argumentando que a diferença não precisa representar uma hierarquia entre diferentes, em que o compartilhamento do tempo e a aproximação (que se relacionam à crítica fenomenológica do conhecimento antropológico) permitem uma prática etnográfica entre sujeitos.

Para além de uma defesa relativista dos povos "tradicionais", o autor se propõe a uma reflexão sobre a estrutura epistemológica em que se assentam as hierarquias de saber. Ele argumenta que a escrita e o registro de grupos "tradicionais" a partir de uma perspectiva de diferenciação essencialista e de distanciamento temporal ("primitivos" e "modernos") colocaria o pesquisador em um tempo distinto dos demais. Fabian, com isso, propõe que no lugar de uma pesquisa sobre determinado grupo, ela seja com eles, em um processo minimamente compartilhado nas estruturas comunicativas dentro de uma determinada comunidade de fala.

Em uma perspectiva que se propunha a um trabalho com interlocutores, e não somente sobre eles, a novidade na experiência fílmica, tanto para pesquisadores quanto para os que seriam protagonistas, foi dando contornos específicos para o trabalho etnográfico. Para fins da discussão que aqui se propõe, serão detalhadas as duas inserções a campo já mencionadas: as atividades realizadas junto às comunidades quilombolas de São Lourenço do Sul e aquelas realizadas na Colônia Maciel, em Pelotas.

Nos vídeos produzidos junto às comunidades quilombolas de São Lourenço do Sul - Comunidade da Picada, na localidade de Santa Tereza; Vila do Torrão, no Canta Galo; Rincão das Almas, no Coqueiro - foram realizadas gravações de práticas que, no amplo leque delas que a memória oferece, mostraram-se como objeto de valorização dos interlocutores e, ao mesmo tempo, passíveis de serem registradas, possibilidade que nem todas as memórias trazem. Mais do que um roteiro em si, os registros se direcionaram para as dinâmicas das atividades desses grupos, caso da produção do vídeo Terno de Reis, junto à Comunidade Quilombola da Vila do Torrão. O Terno de Reis, também abordado em Pinheiro e Rodrigues (2015), é uma expressão musical religiosa que consiste em uma espécie de serenata, realizada nas madrugadas de 01 a 06 de janeiro (dia de Reis), quando 
os reiseiros anunciam de casa em casa a chegada do menino Jesus, com uma série de aproximadamente três músicas. É essencial que aconteça somente de noite, preferencialmente acordando os moradores, que por sua vez devem recebê-los com dons, como bebidas e dinheiro, mas também com comidas.

O Terno de Reis é realizado em diversos locais do Brasil, com reiseiros de diferentes etnias. Porém, há particularidades no caso do grupo acompanhado, pois trata-se de um grupo de morenos a visitar preferencialmente colonos, evidenciando nuances da complexa relação interétnica que se expressa no município, a exemplo da obrigação de abrir as portas de casa aos reiseiros e dar ofertas generosas, indicadoras de abundância dos colonos. Por parte dos reiseiros, o momento expressa orgulho, pois é considerado como de valorização de suas qualidades e talento musical: "tem que valorizar mesmo a raça negra", diziam.

Essa atividade foi iniciada no Torrão com o reiseiro Neri dos Santos, já falecido, e outros moradores deram continuidade a ela. Dadas as dificuldades tanto de deslocamento quanto para o ensaio das músicas, assim como outros fatores (por exemplo, problemas eventuais de saúde entre os mais velhos), há dificuldades em tirar o Reis a cada ano, como era de costume. O deslocamento é uma questão delicada, dado o longo trajeto a cada noite, a idade já avançada de alguns reiseiros e o peso de instrumentos como a gaita (sanfona), sendo que uma opção acessada nas últimas saídas foi o aluguel de veículo - apenas para o deslocamento até o ponto mais distante, de onde retornavam a pé. No entanto, essa opção representa mais um custo sem que haja garantia de recebimento de recursos.

Com essas limitações, os reiseiros ficaram alguns anos sem realizar a jornada e só voltaram a fazê-lo com o apoio de uma técnica que atuava com assistência técnica na comunidade que, em 2010, dispôs-se a ser a motorista dos músicos. Dois anos depois, nos primeiros dias de 2013, foi feita nova incursão com a pesquisadora da equipe da agenda de pesquisa Saberes e Sabores da Colônia, que resultou no vídeo Terno de Reis (2015), com Seu Graciano, Seu Zé da Gaita, Mauri, Círio e Seu João ${ }^{17}$.

\footnotetext{
${ }^{17}$ Seu João (irmão de Seu Graciano e Seu Zé da Gaita) não fazia parte do grupo de reiseiros. No entanto, como naquele momento havia uma relação de interlocução mais próxima com ele e pareceu ser sua vontade participar, ele acompanhou o grupo a pedido da pesquisadora, sem objeção dos demais.
} 
De início, cabe mencionar que a inserção de pesquisa na Vila do Torrão se deu a partir de meados de 2012, mas foi intensificada somente no final daquele ano. Após conversas iniciais com Seu Graciano, o violeiro do grupo, que já havia relatado a importância do Terno de Reis, e com Seu João, seu irmão, morador na Picada (Santa Tereza), foi apresentado às pesquisadoras Seu Zé da Gaita, o gaiteiro, também morador do Torrão, sendo que em dezembro teve início a articulação referente ao apoio ao deslocamento. Era, assim, uma relação em processo inicial e a efetivação da apresentação, apesar de mencionada pelos reiseiros com nostalgia e carinho, não era uma certeza nas conversas que precederam o Terno de 2013.

Apesar da empolgação inicial, até o momento de concentração do grupo para a saída ficou nítido que não havia convicção de que seria possível realizar o Terno naquele ano, pois em sua avaliação eles não haviam ensaiado o suficiente, o que gerava dúvidas entre os participantes, diante da importância atribuída à apresentação. Mas o pedido externo, mesmo que de alguém que não tinha laços prolongados com o grupo, pode ter influenciado na decisão. E todos concordavam com a importância em manter a tradição.

Ao longo das apresentações, a presença de uma pessoa externa acompanhando o grupo exigia, a cada família visitada, uma breve apresentação e justificativa de sua presença, fala geralmente feita por seu Zé, ao final, enfatizando a posição acadêmica e de fora do município da pesquisadora interessada em conhecer o Reis, tomada como evidência do valor de suas práticas. A valorização foi, de modo intenso, tema presente nas duas noites, em conversas entremeadas com desabafos sobre relações trabalhistas consideradas injustas. Ao final das duas noites de apresentações, foi consenso no grupo que o Terno não poderia ser deixado de lado e que para o ano seguinte eles iriam ensaiar ao longo do ano, principalmente os mais novos (o que, devido a problemas de saúde de um dos reiseiros, acabaria não ocorrendo).

Em uma dimensão relacional da produção fílmica, versões prévias dos vídeos e fotografias foram compartilhadas com os reiseiros, gerando novos debates e percepções sobre o processo, de grande riqueza. Além da entrega de materiais preliminares, registros complementares para a produção do vídeo Terno de Reis (com seu Graciano e seu Zé da Gaita) foram realizados ao longo do ano seguinte, assim como se daria com outros vídeos, como aqueles elaborados na Colônia Maciel. Assim, em vez de falar sobre o Outro, para a 
edição das imagens a solução adotada foi de introduzir em voz off a locução dos protagonistas - registradas em situações de entrevista -, descrevendo e refletindo sobre as atividades mostradas no vídeo e suas implicações. Tal solução encontrou inspiração nas estratégias adotadas por Jean Rouch, quando se deparava com limitações técnicas decorrentes da inexistência de som sincrônico com as imagens. Em vez de falar sobre o Outro, Rouch "passava-lhe a palavra", inaugurando, em 1958, não somente a fala de um negro no cinema, mas também, como ressalta Gonçalves (2008), seu direito à fabulação.

O outro processo compartilhado que gostaríamos de destacar foi conduzido na Colônia Maciel, município de Pelotas. Aqui, o processo de diálogo e planejamento sobre as imagens ocorreu a partir da inserção de pesquisa na Festa de Sant'Ana, em 2010, através da incursão da pesquisadora na condição de ajudante das mulheres que trabalham no preparo e realização das festas da comunidade ${ }^{18}$ e, em 2011 , de sua inserção no cotidiano de seis famílias que trabalham nessas festas. Neste contexto foram elaborados dois documentários, um sobre a Festa de Sant'Ana e outro sobre o fabrico do vinho e suco pela família Camelato (Machado, 2011, 2013).

Com relação à elaboração do vídeo da festa de Sant'Ana, o planejamento ocorreu com os interlocutores com a elaboração de um pré-roteiro, buscando-se contar o processo de fazer a festa, desde seus preparativos, passando pela festa em si, até o dia seguinte a ela. As festas de 2012 e 2013 foram o espaço de realização das imagens para elaboração do filme intitulado "Festa na colônia: festa de Sant'Ana", evento que ocorre anualmente no mês de fevereiro, em homenagem à padroeira da comunidade católica Sant'Ana, sendo organizada em forma de mutirão pelas famílias da Colônia Maciel e localidades vizinhas. O preparo da festa inicia ao menos cinco dias antes, com a preparação de comidas e organização do salão, das churrasqueiras e barracas para os jogos. A festividade propriamente inicia com a missa comemorativa, seguida de almoço, café colonial à tarde ${ }^{19}$, baile e jogos. À noite realiza-se baile com discoteca, quando a música eletrônica e outros ritmos vêm substituir a banda tradicional. Todos estes momentos do fazer a festa foram

\footnotetext{
${ }^{18}$ Da mesma forma ocorreu a inserção em outros momentos festivos como no Café Colonial, em 2010 e 2011, e na Festa do Dia do Vinho (um Jantar comemorativo ao dia do vinho), em 2010, 2011, 2012 e 2013.

${ }^{19}$ Este café é denominado "café colonial" em referência à colônia, ou seja, nele são servidos os produtos que os colonos consomem cotidianamente, ainda que não com a variedade e abundância característica do café servido nas festas.
} 
acompanhados pela câmera da pesquisadora, assim como o dia após a festa, dedicado à limpeza e organização do salão.

Outro momento importante foi a inserção - por períodos de um dia - no cotidiano de seis famílias que trabalham nas festas da comunidade, para participação em atividades preparatórias, inserção em que foi evidenciada a importância do vinho como alimento emblemático no cotidiano destas famílias ${ }^{20}$. Entendido como símbolo da identidade italiana, o vinho está à mesa das famílias descendentes destes imigrantes, assim como de descendentes de alemães e brasileiros, o que indica uma identidade colona compartilhada (Seyferth, 1994). A partir deste contexto, após a inserção no cotidiano da família Camelato e acompanhamento por alguns dias o trabalho na propriedade, o fabrico do vinho e do suco de uva foi tomado como tema de um filme, cujo pré-roteiro foi discutido com seus protagonistas. As etapas do fabrico do vinho e do suco foram documentadas em vídeo em fevereiro de 2012, sendo, em 2013, complementado o material fílmico com depoimentos de Seu Jordão e Dona Lourdes.

Por sua vez, a fotografia foi, no decorrer da pesquisa, vetor de trocas com as famílias, principalmente durante os momentos festivos, como a Festa de Sant'Ana, o Café Colonial e a Festa do Dia do Vinho. Cada um destes eventos comemorativos foi motivo de documentação fotográfica restituída em CD no momento da festa seguinte. Fotos impressas foram outro contra-dom oferecido em retribuição pelo acolhimento da pesquisadora e motivo de fortalecimento de vínculos com as famílias que as demandavam.

O processo de elaboração do filme da Festa de Sant'Ana foi uma das formas de diálogo e saber compartilhado para a construção do produto final da pesquisa, com o entendimento de que um processo de restituição não se restringe a produtos finalizados, mas faz parte da pesquisa e da constituição de relação de confiança na transmissão da imagem de sujeitos e práticas. No segundo semestre de 2013, durante a preparação do jantar do Dia do Vinho, um primeiro corte da edição do vídeo da Festa de Sant'Ana foi apresentado à comunidade, sendo tal restituição parcial da pesquisa tema da análise a seguir desenvolvida. As famílias envolvidas no preparo do jantar que ocorreria à noite escolheram o período do café da tarde para assistir ao material fílmico.

\footnotetext{
${ }^{20} \mathrm{Na}$ Colônia Maciel, o vinho é produzido para o consumo familiar e em algumas famílias em maior escala para comercialização.
} 
Nos dias e especialmente nas tardes que antecedem a festa, é grande a mobilização da comunidade para sua preparação, sendo o café da tarde momento em que o trabalho é interrompido. A refeição é servida em duas rodadas: na primeira, os homens tomam o café da tarde, para depois as mulheres o fazerem. Naquela edição do jantar do Dia do Vinho, a cada rodada de café da tarde, procedeu-se à apresentação da primeira versão do filme sobre a Festa de Sant'Ana, precedida por rápida contextualização da pesquisa e produção do vídeo.

Assim que iniciou a primeira projeção, os homens, que estavam de costas para a tela, fazendo a refeição, inclinaram o corpo de forma a assistir ao vídeo no salão. Enquanto isso, do outro lado do balcão, as mulheres, na cozinha, onde realizavam diferentes tarefas, dividiam o olhar entre as panelas e o telão. À medida em que os interlocutores apareciam no filme, os demais homens sorriam e comentavam sobre a desenvoltura daquele que protagonizava a cena. Assim, entre fatias de pão e xícaras de café, conversas, risos e gestos expressivos, eram instigados pelas imagens. Seu Deomar, sentado à ponta da mesa, assistindo ao vídeo em silêncio, abre um sorriso no momento em que se vê no telão, comentando algo baixinho com o senhor sentado ao seu lado. Elda, que trabalhava no espaço da cozinha, fica atenta ao ver-se nas imagens, parecendo emocionada. Os homens, na maior parte do tempo, assistiram ao vídeo em silêncio, com conversas paralelas em tom baixo. Ao final, todos levantaram e aplaudiram, e Emanuele, que conduz toda narração do filme de forma muito articulada, faz um agradecimento à pesquisadora em nome da comunidade. Quando os homens seguiram para suas tarefas, foi a vez das mulheres tomarem seu café e assistirem à projeção.

Da mesma forma que os homens, as mulheres, sentadas de costas para a tela, se organizaram de forma a assistir ao vídeo e alimentar-se. Ao contrário dos homens, elas falavam alto, dando risada e comentando as participações de quem aparecia no vídeo, gesticulando e apontando para a tela. Uma delas comenta como "a Lourdes aparece bastante". Esta, ao lado, sorria, assistindo o filme em pé, enquanto repunha os alimentos que faltavam na mesa. Sentou-se somente quando apareceu, com seu esposo, nas imagens do telão. As mulheres comentaram que as imagens não eram de uma única festa. Ao final do vídeo, enquanto algumas retornaram à cozinha, para retomar o trabalho, assistindo de lá, 
outras permaneceram sentadas, mesmo após terminar a refeição. Elda sorria ao comentar sua fala no vídeo com outras, parecendo avaliar sua performance.

A pesquisa de Hartmann (2004) junto a contadores de histórias da fronteira entre Brasil, Argentina e Uruguai fez uso expressivo de recursos audiovisuais e também contou com momentos de exposição a interlocutores de uma seleção de materiais (em especial fotos) que vinham sendo produzidos no trabalho de campo, estimulando qualidades interpretativas pelo contato entre sujeitos e proporcionando novas conversas e debates sobre as pessoas e temas registrados. Para a autora, as análises realizadas a partir dessa exposição são significativas para a compreensão de elementos que identificam os moradores de cada local, informando sobre relações entre a visão de si e do outro experienciadas no papel de protagonistas. Esses momentos podem ainda explicitar diferenças entre o olhar do pesquisador e dos interlocutores e a importância dada a determinado evento, gesto ou atitude. De todo modo, a autora considera relevantes tais diálogos, pois "Assim como os sujeitos me punham a par, com suas observações, dos interstícios de sua cultura, eu ali expunha, sem atenuantes, meus interesses e minha maneira, na visão deles talvez injusta, de recortar a sua realidade” (Hartmann, 2004: 81).

Segundo Guran (1995), a fotografia pode ser tomada como instrumento de diálogo com a realidade e forma de compreendê-la. Assim, como indica esse autor (2011) diferenciamos a fotografia usada "para descobrir" daquela usada "para contar". O primeiro caso refere-se à sua importância durante o trabalho de campo, momento em que, através da observação participante, o pesquisador se familiariza com o universo de investigação e formula as primeiras questões práticas. Neste processo, a fotografia permite refletir sobre as situações vivenciadas e/ou apreender o que não foi captado in loco. No decorrer da pesquisa, à medida em que o pesquisador procede à análise do material empírico produzido em campo e passa à elaboração da escrita, algumas fotografias tornam-se mais significativas para as elaborações interpretativas do autor, contribuindo para "contar" as experiências vivenciadas no encontro etnográfico. De acordo com Guran (2011, p. 84), neste momento, "a fotografia pode ser utilizada para destacar, com segurança, aspectos e situações marcantes da cultura estudada e para dar suporte à reflexão apoiada nas evidências que a própria imagem apresentar”. 
Nos casos aqui apresentados, assim como no conjunto mais amplo desta agenda de pesquisas, as fotografias e vídeos produzidos cumpriram ambos papéis - tanto de descoberta do universo em questão, quanto de descrição imagética dos saberes e sabores próprios das comunidades estudadas. Mas o potencial da imagem foi além destas funções, na medida em que ela viabilizou a restituição das pesquisas de um modo que a produção escrita não conseguiria fazê-lo. Ademais, a recepção deste material foi experiência considerada positiva e valorizadora de suas práticas e auto representações perante um olhar externo, catalisando vínculos afetivos junto aos interlocutores. Dispostos a contar histórias relativas não somente a um evento particular, como o Terno de Reis ou a Festa de Sant'Ana, mas também a experiências de vida, de trabalho, a relações de parentesco, a amizades e outros aspectos associados aos seus hábitos alimentares, as imagens catalisaram relações entre membros da equipe de pesquisa, das famílias e das comunidades estudadas (inclusive, deles entre si), ativando narrativas sobre suas memórias e reflexões interpretativas sobre suas práticas em transformação diante dos desafios contemporâneos.

Por outro lado, certa expectativa sobre o que aquelas imagens "brutas", sem edição, apresentadas no momento da restituição parcial da pesquisa, poderiam gerar em termos do modo como suas práticas e saberes seriam representados e publicizados foi se formando. No caso de a opção metodológica estar baseada em um processo de construção partilhada do conhecimento, os cuidados com a edição das imagens parecem ser ainda mais sensíveis e acurados.

\section{Performance e guardiania da memória}

Em pesquisa anteriormente mencionada, Hartmann (2004) percorre uma rede de contadores de histórias composta de personagens que habitam a zona fronteiriça estudada, com suas narrativas e performances peculiares, conectadas ao ver e se ver "da fronteira", a partir de uma noção de performance que expressa condutas e padrões de comportamento, gestos e falas que se fortalecem na experiência, apoiados no conhecimento desse conjunto de práticas e na sua habilidade em reproduzi-las socialmente ao longo do tempo (Hartmann, 2005). 
Nessas performances, a autora enfatiza que a habilidade dos narradores em lidar com os estímulos de seus espectadores (incluindo os instrumentos de gravação) e o desempenho assumido diante desses instrumentos foi expressa desde o primeiro momento da sua pesquisa. Claro, a performance do narrador no momento de registro imagético não é somente estimulada pela presença da câmera (que pode mesmo dificultar alguns relatos), mas também pela complementaridade do diálogo entre narrador e ouvintes. Sobre essa comunicação que se estabelece através de condutas, expressões corporais, sons e outros elementos, as entrevistas gravadas em vídeo são mencionadas como eventos narrativos por Devos (2007: 140), que argumenta que "Esse diálogo entre o narrador e seus ouvintes é justamente a condição desse contar (e ouvir) histórias. Um não existe sem o outro”.

Nos casos aqui mencionados das pesquisas sobre saberes e sabores da colônia, as situações discursivas assumidas pelos interlocutores foram múltiplas, com as especificidades de um diálogo em que o ouvinte é também o pesquisador (oriundo de contexto cultural distinto do narrador). Com a consciência das limitações em expressar a totalidade das experiências performáticas, serão apresentadas algumas impressões sobre os eventos narrativos relacionados às duas inserções de pesquisa antes mencionadas.

No contexto da Colônia Maciel, como vimos, os dois vídeos elaborados narram, respectivamente, o fabrico do vinho e do suco de uva pela Família Camelato e a Festa de Sant'Ana, tendo sido concebidos e elaborados também como restituição da pesquisa previamente realizada junto aos interlocutores (em 2012 e 2013). No processo de fabrico do vinho, o vídeo é constituído a partir das falas e demonstrações de Seu Jordão Camelato, o narrador, e de sua esposa Dona Lourdes, seus filhos Alison, José e Luís Maurício. Já no processo de fabrico do suco de uva a narradora é Emanuele, nora de Seu Jordão e de Dona Lurdes.

No que se refere à narrativa do fabrico do vinho, Seu Jordão conta a história da família, desde a chegada dos antepassados imigrantes italianos na Colônia Maciel, evidenciando que o saber fazer do vinho tem sido transmitido através das gerações. Entre uma fase e outra do processo (colheita da uva, desengace do fruto do talo, repouso para fermentação do mostro, transferência para as pipas pelo tempo determinado e envasamento), Seu Jordão fala de sua família e das práticas na agricultura. Também relata a introdução de novas variedades de uva, de máquinas para seu processamento e de técnicas 
que dialogam com saberes e práticas dos antepassados. Referindo-se aos itens produzidos pela unidade familiar para comercialização, Seu Jordão menciona que o vinho tem lugar secundário, mas argumenta que a família produz a bebida porque "gosta de vinho". Dona Lourdes conta que o vinho é consumido diariamente pela família, que seus filhos aprenderam a gostar da bebida ainda crianças e que a produção é feita em primeiro lugar para abastecer a família, depois para comercialização. Cabe mencionar o lugar escolhido por Seu Jordão para gravar seu depoimento, ao lado da parreira, segurando seu tronco. Já dona Lourdes conduz a pesquisadora e a câmera à cozinha: apenas depois de acomodar-se ali, permite que seu depoimento seja gravado.

No que se refere ao preparo do suco de uva, em que são evidenciadas as suas etapas, é Emanuele, com seu jaleco branco, quem o prepara e narra o processo, apontando elementos importantes: a produção de suco é de responsabilidade do jovem casal e, por ser enóloga, a esposa é a narradora. Ainda, enquanto Seu Jordão narra o fabrico do vinho, ancorado na história dos antepassados, e posicionado ao lado do parreiral, Emanuele demonstra o fabrico do suco, embasada no conhecimento técnico apreendido na universidade, presente em sua fala e vestir, materializados no jaleco branco. Evidenciando o saber fazer do vinho e do suco de uva, este vídeo possibilita diálogos sobre a família e suas raízes, o cotidiano das pessoas do lugar e sua identidade enquanto colonos. Daí constituirse enquanto instrumento de restituição da pesquisa.

O outro vídeo sobre a festa em homenagem a Sant'Ana, padroeira da comunidade católica local, foi proposto por ser uma confraternização emblemática da comunidade, além de porta de entrada da pesquisadora à localidade e ao cotidiano de algumas de suas famílias. À medida em que as famílias que fazem a festa iam se apropriando do processo de filmagem, ao longo dos preparativos, demandavam cenas: "venha nos filmar podando as árvores", "venha fotografar a tirada de cucas do forno", "filma a Elda enfeitando o bolo". A cena final do vídeo, em que, no dia seguinte ao da festa, um menino auxilia Seu Jordão Camelato a varrer a área do salão, foi filmada por solicitação de Seu Jordão.

A protagonista do filme é uma jovem, à época, presidente da comunidade. Sua narração, descrevendo a festa, é entremeada com depoimentos de pessoas mais velhas, envolvidas com sua realização há décadas. Alguns deles - no mais das vezes casais tomam a palavra: Seu Deomar, que coordena os assadores na preparação do churrasco; 
Dona Lourdes - responsável por preparar as refeições da equipe que trabalha na festa - e Seu Jordão Camelato; Nelda - que prepara os doces e o café colonial da festa -, juntamente com o esposo Valdir; e Seu Bento e Dona Maria. Estes, assim como outros interlocutores, fazem a festa e a narram a partir de um diálogo entre presente e passado, que possibilita compreender relações que conformam o festar, a partir do trabalho, da religião e da comida.

Já no vídeo Memórias Negras sobre a Alimentação (2015), a elaboração de polenta recheada, de um bolo de torresmo e do quibebe, todos alimentos preparados à base de farinha de milho, é entremeada pelo relato de Dona Eva Maria, do Rincão das Almas, sobre as memórias suscitadas sobre o milho e outros alimentos do tempo antigo. De um cinza profundo, os olhos de dona Eva, sentada em frente ao galinheiro de sua pequena propriedade, em que mora com a filha e sua família, mostram suas experiências de sofrimento, perseverança e amorosidade, contadas em tom de voz tranquilo, expressando memórias sobre a territorialidade negra em São Lourenço do Sul. Dona Maria Gessi, da Picada, que também protagoniza este vídeo (além de um outro, Schimia de Melancia de Porco, 2015), apresenta falas mais breves e relacionadas à descrição das práticas, sem jamais perder o entusiasmo.

Já os irmãos Graciano e Zé da Gaita, da Vila do Torrão, ambos músicos, protagonistas do já mencionado filme Terno de Reis (2015), assumiram o papel de narradores, a partir de uma cadência de gestos que fazia com que a narrativa fosse contada com todo o corpo. Com riqueza de detalhes, pela boa memória da qual Seu Graciano se orgulha, como guardião que é, ele traz diversos relatos, carregando seu violão, pronto para ser acionado, em uma cadeira em frente à sua casa. Por meio de sua fala, somos apresentados à sua mãe e avó, já falecidas, ambas gaiteiras, e a seu sogro, também falecido, o primeiro reiseiro da comunidade. Seu Graciano também relata os desafios das primeiras saídas do Terno de Reis, seu aprendizado autodidata na música, com o violão, entre outras questões. Narrativas sobre elementos que conferem singularidade ao território da Vila do Torrão, como a presença de assombros, bruxas e lobisomens, também foram acionadas nesta entrevista, porém não foram usados pela limitação de tempo do vídeo e por ultrapassarem sua temática. 
Um fator que se ressalta no vídeo é o dom, operado por ambos, de tornar as narrativas relatos contagiantes. Seu Zé da Gaita, que também é artesão, descreve os elementos mais importantes do Terno: é preciso chegar de noite, de casa em casa, cantando os versos do Reis. Os moradores, por sua vez, devem recebê-los, abrindo as portas de suas casas, com a oferta espontânea de bebidas, dinheiro ou comida, como ele relata. E faz questão de enfatizar sua relação de proximidade com os vizinhos colonos, como quando menciona que a reativação mais recente do grupo de reiseiros foi realizada com apoio de um deles.

Os narradores mencionados acima, situados na faixa etária entre 50 e 70 anos, podem ser considerados guardiões da memória do $\operatorname{lugar}^{21}$. Eles conectam suas trajetórias com as memórias e identidades coletivas de modo complexo, pois a experiência de vida de uma pessoa não necessariamente expressa a experiência coletiva de um grupo, apesar de se conectar a ele, tampouco uma identidade coletiva seria o somatório das experiências dos indivíduos ou simples transposição de depoimentos. Para Halbwachs (1990), a memória individual pode acionar ou mesmo se confundir com a memória coletiva, mas ainda assim podem seguir caminhos distintos. No entanto, essas trajetórias fazem parte de processos de significação das experiências coletivas em torno de eixos de diferenciação que recebem significados particulares com a priorização de alguns traços e elementos da memória em detrimento de outros.

As lembranças coletivas evocadas por determinado grupo, ressalta-se, frequentemente fogem de uma linearidade do tempo ou de uma delimitação fixa de espaço, mas se relacionam à importância dada às memórias pelo grupo e suas relações sociais. São atravessadas por pontos de vista distintos, por experiências pessoais, mas também acionam noções comuns a seus membros, assim como engajamentos, afetos, divergências e solidariedades (Halbwachs, 1990).

As memórias coletivas, com isso, através de depoimentos desses narradores sobre eventos, práticas e situações dos quais se desdobram as relações do e entre o grupo, lembram pessoas, experiências, conquistas e desafios. Coletivamente, essas lembranças são compartilhadas, modificadas e algumas podem ser fortalecidas nesse processo. Elas

${ }^{21}$ Também interlocutores mais jovens participaram dos vídeos, mas em número reduzido. 
rememoram uma série de eventos e situações cotidianas que determinado grupo vivenciou e elevam esses indivíduos a testemunhas das experiências individuais e coletivas.

\section{O encontro entre protagonistas, comunidades rurais e pesquisadores na restituição dos produtos imagéticos}

Na restituição dos produtos imagéticos finalizados aos interlocutores, uma série de questões têm emergido sobre a relação estabelecida ao longo da pesquisa, agora não somente entre pesquisadores e protagonistas dos documentários, mas também com a possibilidade de expansão das representações construídas sobre/com esses grupos junto a um público mais amplo, em especial no espaço rural. Com isso, está em jogo também a imagem de si, por parte dos interlocutores, representada nesses materiais e apresentada a diferentes comunidades rurais que fazem parte de sistemas de relações locais, incluindo relações interétnicas complexas presentes nos núcleos coloniais da Serra dos Tapes.

Após a finalização do conjunto de produtos da pesquisa Saberes e Sabores, em especial o box multimídia com os dez documentários, o cd-rom interativo e o livreto de receitas, uma nova etapa da pesquisa se configurou em 2015, cerca de dois anos após a captação das imagens e entrevistas: a entrega e apresentação dos materiais finalizados, em um primeiro momento diretamente aos interlocutores, partilhando a exibição em seus núcleos familiares. No entanto, esse reencontro entre pesquisadores e interlocutores abriu novas possibilidades de difusão do material, que incluíram escolas do espaço rural. Com isso, se a distribuição dos produtos fora, desde o início da pesquisa, organizada de modo a contemplar a multiplicação dos materiais imagéticos, sua apresentação e debate em algumas escolas foram concretizados a partir desse reencontro.

Mais especificamente, as apresentações em escolas foram fruto de um processo de diálogo entre pesquisadores e alguns interlocutores de São Lourenço do Sul, em especial das comunidades quilombolas que participaram da pesquisa, de modo a abranger escolas que as crianças e jovens quilombolas frequentam. Essa proposta começou a ser gestada ainda no período em que a pesquisa foi elaborada, a partir de dois elementos que foram objeto de reflexão compartilhada. O primeiro, a ideia de que após a finalização de uma pesquisa acadêmica, é necessário - ainda que pouco frequente - o retorno dos pesquisadores, para compartilhamento do trabalho. O outro, o entendimento de que seria 
importante realizar a apresentação do material em escolas próximas às comunidades em que vivem os interlocutores, dado que, por um lado, muitas famílias não possuem computadores ou equipamentos para exibição de vídeo e, por outro, esses interlocutores identificaram no material uma forma de comunicação de suas práticas que poderia ser apresentado a seus vizinhos colonos. Além disso, já à época da pesquisa houve demanda por parte da escola próxima à Comunidade Quilombola da Picada para que fossem disponibilizados materiais de uso escolar sobre o grupo, apontados pelos professores como inexistentes até então. Assim sendo, o objeto de reflexão do presente texto também passa pelo debate sobre o lugar que a imagem assume para esta pesquisa no momento de sua difusão.

No entrecruzamento entre pesquisadores, interlocutores e comunidade rurais, um vídeo pode atravessar realidades culturais distintas e mesmo dissonantes ou conflituosas. Por sua polissemia, pode provocar múltiplas interpretações, marcadas por impressões, percepções e representações de cada um, que emergem no encontro entre espectadores e imagens (MacDougall, 1997). No caso desta pesquisa, não cada filme individualmente, mas o conjunto deles nos faz confrontar com intersecções entre mundos distintos, mostrando um universo colonial diverso, permeado por tensionamentos e hierarquias sociais e culturais, nem sempre explícitos. Com isso, a apresentação para públicos mais amplos foi um desafio e também potencializou tanto a abertura de diálogos quanto o tensionamento de relações sociais locais.

A experiência de divulgação das imagens para além do espaço de comunicação entre quem filma e quem é filmado carrega o desafio da publicização de representações (do Outro e sobre o Outro), no qual a capacidade narrativa pode ser legitimada e potencializada com o estar no vídeo a ser apresentado publicamente. No caso em questão, a complexidade aumenta, pois são vídeos que trazem sujeitos muito diversos e que no interior das colônias conformam redes de relações que ora são de proximidade e diálogo, ora de tensão. Com isso, para além de divulgação de produtos imagéticos, a apresentação do material junto às escolas se propôs a debater uma diversidade de práticas em uma arena de intersubjetividades composta por várias perspectivas, que se encontravam neste momento de interpretações das imagens a partir de suas próprias experiências e representações. Em tal encontro, abre-se a possibilidade de reconhecimento de uma condição de sujeito para grupos que pouco figuram na condição de protagonistas. 
Com isso, nos eventos de apresentação dos produtos imagéticos a recepção das imagens dialoga entre interpretações individuais e coletivas dos protagonistas dos vídeos e de suas práticas, o que potencializa a relevância (nem sempre positiva) de tornar pública determinada imagem dos interlocutores. E a questão se redefine de mera divulgação de resultados da pesquisa, para, por um lado, reafirmação ou distanciamento na relação entre pesquisadores e interlocutores e, por outro, em deslocamentos de imagens estigmatizadas que podem vir a trazer implicações para o sistema de relações locais (que não necessariamente são de reversão de estigmas, podendo ser também de ciúmes ou desconfiança).

Se não é possível mensurar as implicações, usos e desdobramentos do material imagético, é relevante refletir sobre esses momentos de difusão, apresentação, recepção e ressignificação, o que inclui os modos como as imagens são recebidas pelos interlocutores nestes eventos públicos e como isso impacta, a curto, médio e longo prazo, sobre essas pessoas e coletividades e sobre a própria etnografia. Ou seja, não se trata somente de um método, mas de uma reflexão epistemológica, que tampouco ignora a presença do realizador como participante da pesquisa.

Para Bellegarde (2003), há na restituição uma espetacularização do objeto de estudo para um determinado público, do qual em alguma medida o pesquisador participa e para o qual o retorno das informações deve ser acessível. Nessa teatralização (um drama social) também se consolida uma representação do objeto de estudo, além de se explicitar sentimentos, ordenar sensações e institucionalizar fatos. Há uma relação direta da identificação do público e sua capacidade em reconhecer o discurso comunicado (Bellegarde, 2003).

Vale (2014) chama a atenção para a importância de uma antropologia da restituição como parte da pesquisa, e da assim chamada "estética da recepção" em suas múltiplas materializações, seja em ambiente privado ou público, restrito aos protagonistas ou não, de acordo com a situação vivenciada. Pode englobar ainda outros espectadores, atingindo públicos diversos, que possuem relação direta ou não com os protagonistas. 
O jogo que a restituição estabelece indica um lugar preciso: ela implica em relações de poder e dominação pensadas em termos macro e microscópicos, cuja capilaridade se estende por todo o tecido social. Nos momentos de embate em torno da restituição, a reivindicação pela representação legítima e pelo uso legítimo dessa representação concentra, condensa, atualiza e revela essas lógicas políticas. De uma maneira ou de outra, a restituição é algo esperado pelos/as interlocutores/as da pesquisa. (Vale, 2014; p. 184).

Além disso, os momentos de retorno e restituição promovem um certo rompimento da autoridade da autoria, dado que há uma avaliação dos interlocutores ou do público mais amplo sobre os produtos imagéticos e sobre a realidade captada satisfatoriamente ou não. Pode ser ainda alvo de conflitos de interpretações, de frustração e não identificação de sua imagem no filme por parte dos protagonistas em sua infinidade de ressignificações, como menciona Vale. Ou ainda a perda de confiança em uma interlocução sem ruídos e na possibilidade de representação realista captada nas imagens, dado que a imagem registrada pode não suscitar satisfatoriamente nos interlocutores uma identificação. Podem ainda explicitar regras, valores e condutas que os interlocutores não desejam dar visibilidade. Diante desses inúmeros desafios, Vale advoga a favor de uma antropologia colaborativa, de modo a realizar uma partilha de poder entre o detentor dos instrumentos técnicos e os interlocutores no registro da sua imagem, evitando assim os riscos mencionados. Mas ressalta que também não é uma tarefa simples (e talvez jamais suficiente), dada a polifonia entre os próprios protagonistas em torno de suas expectativas.

A partir das questões trazidas no diálogo com os interlocutores, até o presente quatro escolas da região - três em São Lourenço do Sul e uma em Canguçu - foram contatadas para a apresentação do material: a escola Germano Hübner, na localidade de Santa Teresa (próxima da Comunidade Quilombola da Picada), a escola Sady Hammes, no Coqueiro (próxima do Rincão das Almas), a escola Rodolpho Krüger, no Cantagalo (próxima da Vila do Torrão) e a escola José Veridiano Ferreira, na Colônia Palma (5 Distrito de Canguçu).

A composição dos alunos dessas escolas é majoritariamente de colonos, em especial descendentes pomeranos, com número bastante reduzido de jovens de outras origens étnicas, com exceção da escola Sady Hammes. Essa escola foi também a mais próxima da sede do município de São Lourenço do Sul a ser visitada, com intenso diálogo com a cidade e composição étnica mais diversa. Como a escola está desenvolvendo diversas iniciativas 
relacionadas à alimentação (incluindo uma feira com produtos elaborados pelos pais dos alunos), as professoras identificaram nos produtos imagéticos da agenda de pesquisa Saberes e Sabores da Colônia um material de consulta com informações importantes e valorização de referências locais, que diferem da usual ênfase a elementos "de fora" ou citadinos como melhores.

Em todas as escolas visitadas até o momento, após o contato prévio, a equipe realizou a apresentação dos produtos para um público bastante heterogêneo, que incluía professores, interlocutores (que também foram espectadores), jovens e crianças de todas as séries do Ensino Básico. Na escola Rodolpho Krüger, Seu Graciano participou com muita desenvoltura da atividade, contando para os alunos sobre o Terno de Reis. Na escola Sady Hammes, Dona Eva Maria representou a comunidade quilombola do Rincão das Almas, já na Germano Hübner, no turno da tarde, além de Dona Maria Gessi e três de seus filhos, outros moradores da Picada e das redondezas participaram. Cabe registrar que Dona Maria, por iniciativa própria, convidou outras pessoas - algumas com quem a equipe de pesquisa não havia tido qualquer contato prévio -, considerando o momento como importante para a comunidade ver-se nos vídeos.

Nesses eventos, percorremos vídeos e fotos sobre diferentes práticas que perpassam os núcleos coloniais, em grande parte constituintes do cotidiano de alunos e professores: a elaboração do peito de ganso defumado, de Schimia e Schmier de melancia de porco elaboradas respectivamente por famílias rurais quilombolas e pomeranas -, de polentas, canjicas, cucas, quibebes, vinho e suco, e também festas de comunidades religiosas e apresentações de músicos locais com o Terno de Reis. Ao mesmo tempo, procurava-se estimular a reflexão sobre a importância do conhecimento referente à alimentação local.

Durante as apresentações, o diálogo foi profícuo, em especial com os alunos. Em algumas escolas as reações ocorriam de modo mais discreto, em outras mais intensamente, mas em todas houve bastante debate e à medida em que mostrávamos fotos e vídeos, surgiam caretas, sorrisos, interpretações e relatos. Procuramos estimular os alunos a comentar sobre com o que se identificavam ou o que chamava a atenção nos vídeos, sendo que a maioria das comidas era de conhecimento de todos e muitos já haviam participado na elaboração dos preparos, de festas e outras atividades mostradas, como carneações. Em alguns casos, como no fazer do peito de ganso, contavam conhecer e já haver comido, mas 
a maioria desconhecia seu processo de elaboração, que inclui defumação. Em diversos momentos, nas apresentações dos vídeos, ocorreu o reconhecimento de pessoas e atividades mostradas. Os semblantes dos espectadores ora demonstravam entusiasmo, por reconhecer os interlocutores, ora surpresa, por essas pessoas estarem em posição de protagonismo em filme, o que não é usual.

Segundo as professoras das escolas, esses eventos tiveram acolhida bastante positiva, justamente pela identificação imediata com muitas das imagens apresentadas. Outro aspecto destacado foi a diversidade de grupos abarcados no material, que potencialmente facilita o diálogo intercultural. Os pontos de vista e as reações ao material, no entanto, são variadas. Diante da diversidade de perspectivas e evocando elementos do universo de experiências pessoais de quem observa, no momento da recepção, emergem interpretações polissêmicas dos vídeos, algumas justamente demarcando diferenças entre os grupos retratados, dada a complexidade das relações interétnicas na região.

A partir de uma perspectiva que considera que o olhar também é culturalmente construído, Hartmann (2004) menciona que, no local por ela pesquisado (que atravessa três nacionalidades diferentes), ele se voltava mais para o outro do que para si, parte de relações de alteridade específicas potencializadas pela condição fronteiriça, com afinidades e modos de diferenciação. Entre os diferentes olhares que se interseccionam nas apresentações, as interpretações e apropriações do material fogem aos objetivos iniciais deste processo de restituição, dadas as possibilidades em aberto e indeterminadas na imagem fílmica, em especial naquelas que abarcam uma diversidade de atores sociais. Mesmo que abordada intensamente a diversidade cultural e étnica da Serra dos Tapes, há, nos comentários e observações, direcionamentos e ênfases, por exemplo, em vídeos e fotos de determinados grupos e não de outros.

\section{Por uma antropologia "de longa duração": algumas considerações}

Se tomamos as culturas alimentares dos grupos abordados na agenda de pesquisa Saberes e Sabores da Colônia como patrimônio alimentar, as ações e produtos imagéticos destinados à restituição da pesquisa podem ser entendidos como catalisadores de salvaguarda (independentes da ação do Estado enquanto tal). Assim, ao servir-se de imagens como vetores de difusão e valorização dessas práticas junto a um público mais 
amplo, especialmente novas gerações, pesquisadores e interlocutores contribuem no sentido da salvaguarda destes saberes e práticas.

Quando o material da pesquisa Saberes e Sabores da Colônia é entregue em núcleos familiares, a conversa invariavelmente discorre sobre a importância do momento de retorno - frequentemente negligenciado -, posterior à coleta de dados para a pesquisa, bem como das possibilidades abertas pelo material imagético. Na Picada, quando Dona Maria Gessi recebeu o material, apesar de dificuldades que a comunidade passava naquele momento, com o falecimento de dois moradores, foi acordado que seria feita a apresentação na escola e que seria importante que os registros tivessem continuidade, trazendo novas receitas à tona, como também ocorreu no núcleo familiar de Dona Eva Maria.

Nesses diálogos, foi possível perceber que o processo de continuidade da relação de pesquisa estabelecida junto aos interlocutores, com a entrega e difusão dos produtos oriundos do trabalho etnográfico, é ainda um desafio, que muitas vezes sequer se realiza na forma de simples retorno formal. Para além dele, as propostas que procuram incorporar e estimular a apropriação (alheia aos objetivos acadêmicos, em determinadas situações) dos sujeitos são ainda incipientes. $\mathrm{O}$ relato dos interlocutores que participaram da restituição foi feito no sentido de reforçar o rompimento com uma perspectiva unilateral de pesquisa acadêmica, na qual o conteúdo pesquisado não é demonstrado e tampouco as críticas são ouvidas.

Argumentamos que, em consonância com a perspectiva proposta por Fabian (2006) relacionada à coetaneidade, antes comentada, a relevância dada ao compartilhamento do tempo e à aproximação podem favorecer uma prática etnográfica entre sujeitos, que não restringe as relações de produção de conhecimento ao tempo do pesquisador. Nesse sentido, as imagens, enquanto vetores e catalisadores de saberes sobre os sabores deste mundo rural fomentam a sua circulação, assim como a reflexão sobre o papel do tempo, da interações e das mudanças relativas aos contextos e aos agentes em questão. Elas viabilizam, nos termos de Banks (2014), um potencial pouco explorado no método etnográfico: uma abordagem longitudinal.

No complexo encontro de intersubjetividades que o trabalho etnográfico com o uso de recursos imagéticos permite, nem sempre as reações serão positivas, pois também há surpresas em visualizar as próprias práticas por outro olhar. Pode ainda haver mudanças em 
relação ao momento de captação das imagens, ou outras questões, o que é relevante em uma perspectiva de pesquisas a longo prazo, compreendendo o tempo como intrínseco aos relacionamentos. Todavia, mesmo que atualmente a escrita ou mesmo o uso de ferramentas multimídia não seja um demarcador de distinção tão intenso como foi no passado, ainda há muitos limites neste reposicionamento dos sujeitos e das formas de produção de conhecimento.

A imagem, como perigo e potência, comunica determinados elementos, sendo que entre pesquisadores, interlocutores e "espectadores" não há meros observadores passivos. A imagem pode potencializar e amplificar determinado sujeito ou evento, ao dar-lhe visibilidade, mas o que é visível também depende dos significados anteriores atribuídos a esses sujeitos ou situações que protagonizadas nos filmes.

\section{Referências}

BANKS, Marcus. "Slow Research: exploring one's own visual archive". In: Cadernos de Arte e Antropologia. Dossiê: Imagem, pesquisa e antropologia, vol. 3, n.2, pp. 57-67, 2014. BARBOSA, Andréa; CUNHA, Edgar T. Antropologia e imagem. Coleção Passo a Passo. Rio de Janeiro: Zahar, p. 70, 2006.

BARTHES, Roland. Pour une psycho-sociologie de l'alimentation contemporaine. Annales. Économies, Sociétés, Civilisations, n. 5, p. 977-986, 1961.

BELLEGARDE, Patrick. Institutionnalisation, implication, restitution. L'Homme et la société, Paris, v. 147, n. 1, p. 95-114, 2003. Disponível em: www.cairn.info/revue-1homme-et-la-societe-2003-1-page-95.htm. Acesso: 20 out 2015.

BOSENBECKER, Patrícia. Uma colônia cercada de estâncias: imigrantes em São Lourenço/RS (1857 - 1877). Porto Alegre: UFRGS, p.166, 2011. (Mestrado em História). Programa de Pós-Graduação em História, Universidade Federal do Rio Grande do Sul. Porto Alegre, 2011.

COSTA, Luciano Souza. Anastácia, Manuel Barbosa e Ferreira-Fialho, famílias e territórios negros: tradição e dinâmica territorial em Gravataí e Viamão, RS. Porto Alegre: UFRGS, 2007. 138f. Dissertação (Mestrado em Antropologia Social) Instituto de Filosofia e Ciências Humanas, Universidade Federal de Rio Grande do Sul, Porto Alegre, 2007.

DEVOS, Rafael Victorino. "Filmes de memória" como hipertextos. Revista Chilena de Antropologia Visual, Santiago, n. 10, p. 137-162, 2007.

FABIAN, Johannes. Entrevista: A prática etnográfica como compartilhamento do tempo e como objetivação. Mana, v. 12, n. 2, p. 503-520, 2006.

GONÇALVES, Marco Antônio. Filme ritual e etnografia surrealista: Os Mestres Loucos de Jean Rouch. In: __ O real imaginado: etnografia, cinema e surrealismo em Jean Rouch. Rio de Janeiro: Topbooks, p. 95-162, 2008.

GURAN, Milton. Entrevista. Horizontes Antropológicos - Antropologia Visual. Porto Alegre: PPGAS/UFRGS, ano 1, n. 2, p. 159-166, 1995. 
Considerações sobre a constituição e a utilização de um corpus fotográfico na pesquisa antropológica. Discursos Fotográficos. Londrina, v.7, n.10, p. 77-106, 2011.

HALBWACHS, Maurice. A memória coletiva. Vértice: São Paulo, p. 189, 1990.

HARTMANN, Luciana. "Revelando" Histórias: os usos do audiovisual na pesquisa com narradores da fronteira entre Argentina, Brasil e Uruguai. Campos, Curitiba, v. 2, n. 5, p. 65-86, 2004.

- Performance e experiência nas narrativas orais da fronteira entre Argentina, Brasil e Uruguai. Horizontes Antropológicos, v. 11, n. 24, p. 125-153, 2005. Disponível em: <http://www.scielo.br/scielo.php?script=sci_arttext\&pid=S0104718320050002 00007\&lng=en\&nrm=iso >. Acesso: 12 set 2015.

HEIDER, Karl G. Uma história do filme etnográfico. Cadernos de Antropologia e Imagem. Antropologia e Cinema: primeiros contatos. Rio de Janeiro. v. 1, p. 31-54, 1995.

LÉVI-STRAUSS, Claude. O totemismo hoje. São Paulo: Abril Cultural, 1976.

LÉVI-STRAUSS, Claude. O triângulo culinário. In: SIMONIS, Yvan. Introdução ao estruturalismo: Claude Lévi-Strauss ou "a paixão do incesto". Lisboa: Moraes, 1979 [1968].

MACDOUGALL, David. De quem é essa estória? Cadernos de Antropologia e Imagem, Rio de Janeiro, v. 5, n. 2, p. 93-105, 1997.

MACHADO, Carmen Janaina Batista Machado. Comida, simbolismo e identidade: um olhar sobre a constituição da italianidade nas colônias Maciel e São Manoel - Pelotas - RS. 91f. Monografia (Trabalho de Conclusão do Curso de Licenciatura em Geografia). Universidade Federal de Pelotas, Pelotas, 2011.

MACHADO, Carmen Janaina Batista; MENASCHE, Renata. Uma festa antiga e outra à antiga: significados do rural contemporâneo observados a partir de práticas alimentares. CUALLI Latin American and Iberian Food Studies Review, v. 1, p. 2-21, 2013.

MACIEL, Maria Eunice; MENASCHE, Renata. Alimentação e cultura, identidade e cidadania: você tem fome de quê? Democracia Viva, Rio de Janeiro, n. 16, p. 3-7, 2003.

MACIEL, Maria Eunice. Identidade cultural e alimentação. In: CANESQUI, Ana Maria; GARCIA, Rosa (Org). Antropologia e Nutrição. Um diálogo possível, Rio de Janeiro: Fiocruz, p. 49-55, 2005.

MAESTRI FILHO, Mário José. Deus é grande, o mato é maior: história, trabalho e resistência dos trabalhadores escravizados no Rio Grande do Sul. Passo Fundo: Ed. UPF, p. 232, 2002.

MARTINS, José de Souza. Sociologia da fotografia e da imagem. São Paulo: Contexto, p. 208, 2011.

MENASCHE, Renata (Org.). Saberes e sabores da colônia: alimentação e cultura como abordagem para o estudo do rural. Porto Alegre: Ed. UFRGS, p. 344, 2015.

MENASCHE, Renata; TURRA-MAGNI, Claudia; BRUSCHI, Mauro (Org.). Saberes e Sabores da Colônia: CD-ROM interativo e livreto de receitas. CD-ROM. Pelotas, RS, 2015a.

(Org.). Saberes e Sabores da Colônia: conjunto de vídeos. Vídeo. Pelotas, RS, 2015b. Disponível em: https://vimeo.com/115972212.

PIAULT, Marc-Henri. Anthropologie et Cinéma. Paris: Nathan, 2000.

PINHEIRO, Patrícia Santos. Políticas de identificação: dinâmicas de valorização identitária de comunidades negras rurais no sul do Brasil. 225f. Tese (Doutorado em Ciências Sociais). Programa de Pós-Graduação em Ciências Sociais em Sociedade, Agricultura e Desenvolvimento, Universidade Federal Rural do Rio de Janeiro, Rio de Janeiro, 2015. 
PINHEIRO, Patrícia Santos; RODRIGUES, Carolina Vergara. Entre memórias e ressignificações de práticas alimentares: um estudo sobre alimentação em comunidades negras rurais. In: MENASCHE, Renata (Org.). Saberes e Sabores da Colônia. 1ed. Porto Alegre: Ed. UFRGS, p. 243-266, 2015.

RIAL, Carmen. Brasil: primeiros escritos sobre comida e identidade. In: CANESQUI, Ana Maria; GARCIA, Rosa Wanda (Org.). Antropologia e Nutrição. Um diálogo possível. Rio de Janeiro: Fiocruz, p.87-100, 2005.

SALLES, João Moreira. "A dificuldade do documentário". In: Martins, José Souza; Eckert, Cornelia; Caiuby Novaes, Sylvia (Org.). O imaginário e o poético nas ciências sociais. Bauru: EDUSC, p.57-71, 2005.

SCHNEIDER, Maurício. Identidades em rede: um estudo etnográfico entre quilombolas e pomeranos na Serra dos Tapes. 2015. 150f. Dissertação (Mestrado em Antropologia), Programa de Pós-Graduação em Antropologia, Universidade Federal de Pelotas, Pelotas, 2015.

SEYFERTH, Giralda. A identidade teuto-brasileira numa perspectiva histórica. In: MAUCH, Cláudia; VASCONCELLOS, Naira (Org.). Os alemães no sul do Brasil. Canoas: ULBRA, p.11-28, 1994.

TURRA-MAGNI, Claudia et al. Saberes, sabores e imagens da colônia. In: MENASCHE, Renata (Org.). Saberes e Sabores da Colônia. Porto Alegre: Ed. UFRGS, p. 15-32, 2015.

VALE, Alexandre Fleming Câmara. Por uma estética da restituição: notas sobre o uso do vídeo na pesquisa antropológica. Tessituras, Pelotas, v. 2, n. 2, p. 162-200, 2014.

ZARTH, Paulo Afonso. Do arcaico ao moderno: o Rio Grande do Sul agrário do século XIX. Ijuí: Ed. da UNIJUÍ, p. 320, 2002.

Recebido em: 02/11/2015.

Aprovado em: 15/12/2015. 